\title{
EVALUATION OF ANTI-HYPERTROPHIC POTENTIAL OF CAMELLIA SINENSIS IN ISOPROTERENOL INDUCED CARDIAC HYPERTROPHY
}

\author{
DOSS V. A.* , JEEVITHA PARTHIBHAN1, DHARANIYAMBIGAI KUBERAPANDIAN2 \\ Department of Biochemistry, PSG College of Arts and Science, Coimbatore, Tamil Nadu, India \\ Email: victordoss64@gmail.com
}

Received: 25 Jun 2018 Revised and Accepted: 07 Sep 2018

\section{ABSTRACT}

Objective: Camellia sinensis (C. sinensis family-Theaceae) has potent antioxidant activity used in the treatment of cardiovascular disease. The present study evaluates the cardioprotective (anti-hypertrophic) effect of aqueous extract of $C$. sinensis in isoproterenol (ISO) induced cardiac hypertrophic rats.

Methods: The beneficial effect of the green tea extract was examined by the administration of the aqueous extract of the leaves of $C$. sinensis $(100$ $\mathrm{mg} / \mathrm{kg}$ b.w., oral., $7 \mathrm{~d}$ ) in ISO (10 mg/kg b.w., subcutaneous., 7 d) induced cardiac hypertrophic rats with reference to the standard drug, losartan (50 $\mathrm{mg} / \mathrm{kg}$ b.w., oral.,7 d) followed by biochemical estimations of glucose, protein, cholesterol, cardiac marker enzymes namely serum glutamate oxaloacetate transaminase (SGOT), serum glutamate pyruvate transaminase (SGPT) and lactate dehydrogenase (LDH) in serum and heart tissues thus collected at the end of $7 \mathrm{~d}$

Results: The biochemical assays revealed significantly $(\mathrm{P}<0.05)$ increased glucose, protein, cholesterol, cardiac marker enzymes namely serum glutamate oxaloacetate transaminase (SGOT), serum glutamate pyruvate transaminase (SGPT) lactate dehydrogenase (LDH) and significantly $(\mathrm{P}<0.05)$ decreased in ISO induced cardiac hypertrophic rats that were reciprocated by the effect of plant extract.

Conclusion: Thus, this study showed that the aqueous leaf extract of $C$. sinensis possesses potent effect against cardiac hypertrophy. This potential is hypothesized to be due to the phytochemical, Catechin present in the plant that requires further isolation and characterization with respect to anti-hypertrophic therapeutics.

Keywords: Camellia sinensis, Isoproterenol, Cardiac hypertrophy

(C) 2018 The Authors. Published by Innovare Academic Sciences Pvt Ltd. This is an open access article under the CC BY license (http://creativecommons.org/licenses/by/4.0/) DOI: http://dx.doi.org/10.22159/ijpps.2018v10i10.28101

\section{INTRODUCTION}

Cardiovascular disease (CVD) is one of the leading causes of death globally, more people die annually from CVDs than from any other cause. An estimated, 17.7 million people died from cardiovascular diseases in 2015, representing $31 \%$ of all global deaths. Out of these deaths, 7.4 million were due to coronary heart disease and 6.7 million were due to Stroke. Over three quarters of CVD deaths take place in low and middle-income countries. Among 17 million premature deaths (under the age of 70) due to non-communicable diseases in $2015,37 \%$ are caused by cardiovascular diseases and $82 \%$ are in low and middle-income countries.

"Cardiac hypertrophy is the abnormal enlargement or thickening of the heart muscle resulting from increases in cardiomyocyte size and changes in other heart muscle components, such as extracellular matrix". Hypertrophic growth accompanies many forms of cardiovascular diseases such as hypertension, heart failure and valvular disease [1]. It is a response of myocardium to various physiologic and pathologic stimuli that causes the heart to work harder under condition of increased workload [2].

Administration of several medicinal plants have restored the activities of certain serum cardiac enzymes when compared to normal control groups [3]. The active phytoconstituents of various plant species are isolated for the direct use of drugs, lead compounds or pharmacological agents.

Green tea (Camellia sinensis or $C$. sinensis; family-Theaceae) is made from more nature tea leaves, and they may be withered prior to steaming or firing. Although they are also rich in catechins, green tea may have catechins profiles different from other tea with slightly higher levels of oxidation products [4]. Tea catechins can act as antioxidants by donation of a hydrogen atom, as an acceptor of free radicals, interrupting chain oxidation reactions, or by chelating metals [5]. The active ingredients present in the tea leaves is polyphenol and it's the important biological compound [6] Furthermore, this plant has several medicinal values attributed to high polyphenol contents having tremendous impact on health [7] Many of the studies of polyphenols and catechins reports mechanisms with protection against degenerative diseases $[8,9]$. Green tea has hepatoprotective activity [10], antidiabetic effect [11], cardioprotective activity [12], and antimicrobial activity [13] Various formulations of green tea are prepared that can be beneficial via its antioxidant properties against cellular toxicities $[14,15]$. This study anticipates in evaluating the anti-hypertrophic potential of $C$. sinensis by ameliorating the effects of isoproterenol induced cardiac hypertrophy.

\section{MATERIALS AND METHODS}

Chemicals

All the chemicals were purchased as analytical grade from Hi-Media Laboratories, India. Isoproterenol was purchased as Isoprenaline hydrochloride from Sigma-Aldrich. The standard drug losartan was purchased commercially as losarpen (25 mg) tablets from local pharmacy, India. The glucose and cholesterol estimation kits were purchased from Arkray Healthcare Pvt, Ltd., India. The triglyceride kit was purchased from Ensure Biotech Pvt, Ltd., India. The SGOT and SGPT kits were purchased from Microlyn Healthcare Pvt, Ltd., India.

\section{Plant collection and extraction}

The whole plant of Camellia sinensis were collected during the month of December, 2017 from the local areas (folklore shops) of Coimbatore district, Tamil Nadu, India. The plant was dried in shade at room temperature. The dried whole plant was submitted and authenticated (No. BSI/SRC/5/23/2017/Tech/1955) at Botanical Survey of India, Southern Regional Centre, Coimbatore, India. The leaves of $C$. sinensis were shade dried and powdered in a mixer 
grinder. The aqueous extract of $C$. sinensis whole plant was prepared with plant powder: water (1:3) cold macerated for $48 \mathrm{~h}$, filtered and allowed to dry under controlled temperature to yield the dried leaf aqueous extract [16].

\section{Procurement of animals}

Young male Albino rats of Wistar strain $(200 \mathrm{~g})$ procured and the Ethical clearance for handling of experimental animals was obtained from the Institutional Animal Ethics Committee (IAEC) constituted for the purpose and care of laboratory animals as per the guidance of the Committee for the Purpose of Control and Supervision of
Experiments on Animals (CPCSEA), Ministry of Social justice and empowerment, Government of India (CPCSEA/No 387/2018/IAEC) at the PSG Institute of Medical Sciences and Research (PSG IMSandR), Coimbatore.

\section{Experimental design}

The experimental rats were divided into 4 groups of 6 animals in each group. Cardiac hypertrophy was induced to Albino Wistar rats using isoproterenol and simultaneous treatment using the plant extract and the reference drug, losartan was carried out as shown in table 1.

Table 1: Experimental groups of induction and treatment of cardiac hypertrophy

\begin{tabular}{ll}
\hline Groups & Experimental animals \\
\hline Group I & Normal control rats \\
Group II & Isoproterenol (10 mg/kg b.w., s. c.,7 d)[17] \\
Group III & Isoproterenol+Losartan (50 mg/kg b.w., oral.,7 d)[18] \\
Group IV & Isoproterenol+aqueous leaf extract of C. sinensis (100 $\mathrm{mg} / \mathrm{kg}$ b.w., oral., 7 d)[19] \\
\hline
\end{tabular}

After the end of the experimental treatment period $(7 \mathrm{~d})$, the animals were sacrificed under mild chloroform anesthesia. Blood was collected by cardiac puncture and the serum was separated by centrifugation at $5000 \mathrm{rpm}$ for $10 \mathrm{~min}$. The heart tissue was excised immediately and thoroughly washed in saline before use. A $10 \%$ homogenate of the washed animal tissue was prepared using 0.1 M Phosphate buffer ( $\mathrm{pH} 7.4$ ) in potter homogenizer fitted with a teflon plunger running at $6000 \mathrm{rpm}$ for $3 \mathrm{~min}$. The thus prepared homogenate was used for various biochemical assays.

\section{Biochemical estimation}

Serum glucose was assayed using glucose oxidase method (Autospan Liquid Gold Glucose Kit), serum total protein by Lowry's method [20], serum albumin using Bromo cresol green end point assay method (Autospan), estimation of serum total cholesterol using POD-PAP enzymatic end point assay (Autospan), estimations of SGOT and SGPT activities by modified IFCC method (Microlyn) and determination of LDH activity by optimized kinetic assay method (Autospan) followed by estimation of superoxide dismutase (SOD)[21], catalase [22] and glutathione peroxidase (GPx) [23].

\section{Statistical analysis}

Data obtained was expressed as mean \pm SD. Statistical analysis was performed by using the method of distribution statistics (Standard descriptive analysis) and analysis of mean (Student's't' test) using RStatistical Computing and Graphical Tools (formerly AT and T Lucent technology). A probability of $\mathrm{P}<0.05$ was considered significant.

\section{RESULTS AND DISCUSSION}

\section{Effect of ISO and plant extract on the hypertrophic indices}

The gross examination of the heart showed an increase in the heart size in the isoproterenol group when compared to the normal group fig. 1. On anatomical observation no, remarkable cavity effusions in hypertrophic groups were observed. The heart weight/body weight ratio (HW/BW ratio) as evident from table 2 was found to be increased by $78.72 \%$ in the isoproterenol administered rats (group I) when compared to control rats (group II), demonstrating an increase in the heart size. However, Losartan pretreated rats (group III) showed a $22.78 \%$ reduction in the HW/BW ratio when compared to isoproterenol administered rats. Similar to other studies attenuation of the progression of cardiac hypertrophy is indicated with reduced HW/BW ratio in plant extract administered groups [24].

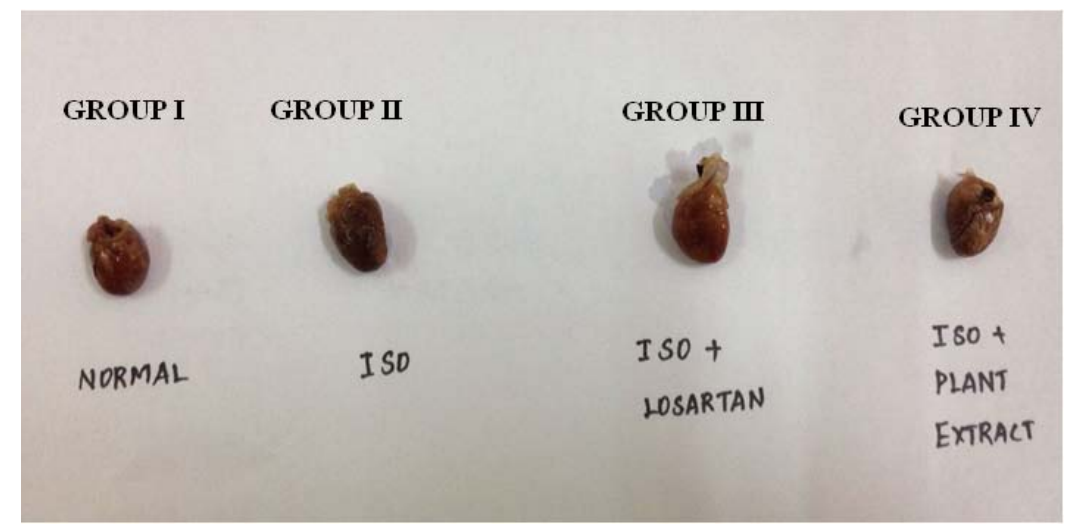

Fig. 1: Examination of the heart size in isoproterenol induced experimental rats and $C$. sinensis treated rats

Table 2: Effect of $C$. sinensis on the HW/BW ratio in the control and experimental rats

\begin{tabular}{llll}
\hline Groups & Heart weight (HW) (mg) & Body weight (BW) (g) & HW/BW \\
\hline Group I & $410 \pm 10$ & $170 \pm 12.92$ & $2.41 \pm 0.77$ \\
Group II & $475 \pm 4.58^{\mathrm{a}^{*}}$ & $187 \pm 16.70^{\mathrm{a}^{*}}$ & $2.54 \pm 0.27 \mathrm{a}^{*}$ \\
Group III & $442 \pm 2.5^{\mathrm{b}^{*}}$ & $190 \pm 17.58^{\mathrm{b}^{*}}$ & $2.33 \pm 0.1 \mathrm{~b}^{*}$ \\
Group IV & $456 \pm 0.6^{\mathrm{c}^{*}}$ & $190 \pm 12.59^{\mathrm{c}^{*}}$ & $2.4 \pm 0.05^{\mathrm{c}^{*}}$ \\
\hline
\end{tabular}

Table values are expressed by mean \pm SD of 6 samples per group. Group comparison: a-Normal (I) Vs ISO (II); b-ISO (II) Vs Drug (III); c-ISO (II) Vs Plant extract (IV). Statistical significance $(\mathrm{P}<0.05)$ indicated by* 
Effect of ISO and plant extract on glucose and total protein in heart tissue and serum

Amelioration of cardiac hypertrophy is indicated by significant decrease in the elevated levels of glucose, protein, total cholesterol and significant increase in reduced HDL cholesterol levels [25]. In isoproterenol induced cardiac hypertrophic rats, the glucose, total protein and total cholesterol levels in serum and heart tissue were significantly $(\mathrm{P}<0.05)$ increased considerably with that of the normal group. After oral administration of the aqueous leaf extract of $C$. sinensis and losartan the glucose levels were restored in experimental animals similar to that of normal control as shown in table 3 and 4 .

Table 3: Effect on serum glucose, total protein and total cholesterol

\begin{tabular}{llll}
\hline Groups & Serum glucose $(\mathbf{m g} / \mathbf{g})$ & Serum protein $\mathbf{( m g / g )}$ & Serum cholesterol (mg/g) \\
\hline Group I & $109.37 \pm 0.26$ & $24 \pm 0.56$ & $28.76 \pm 0.36$ \\
Group II & $141.36 \pm 0.27 \mathrm{a}^{*}$ & $38 \pm 0 \mathrm{a}^{*}$ & $65.58 \pm 1.007 \mathrm{a}^{*}$ \\
Group III & $113.41 \pm 0.28 \mathrm{~b}^{*}$ & $21 \pm 1 \mathrm{~b}^{*}$ & $32.09 \pm 0.07 \mathrm{~b}^{*}$ \\
Group IV & $119.44 \pm 0.325 \mathrm{c}^{*}$ & $16 \pm 0.6 \mathrm{c}^{*}$ & $41.11 \pm 0.10 \mathrm{c}^{*}$ \\
\hline
\end{tabular}

Table values are expressed by mean \pm SD of 6 samples per group. Group comparison: a-Normal (I) Vs ISO (II); b-ISO (II) Vs Drug (III); c-ISO (II) Vs Plant extract (IV). Statistical significance $(\mathrm{P}<0.05)$ indicated by*

Table 4: Effect on glucose, protein and cholesterol in heart tissue

\begin{tabular}{lllll}
\hline Groups & Tissue glucose $(\mathrm{mg} / \mathbf{g})$ & Tissue protein $(\mathrm{mg} / \mathbf{g})$ & Tissue cholesterol $(\mathrm{mg} / \mathbf{g})$ & Serum HDL (IU/l) \\
\hline Group I & $108.52 \pm 0.26$ & $7 \pm 0.56$ & $32.56 \pm 0.36$ & $19.50 \pm 0.036$ \\
Group II & $151.7 \pm 0.27 \mathrm{a}^{*}$ & $21 \pm 0 \mathrm{a}^{*}$ & $68.46 \pm 1.007 \mathrm{a}^{*}$ & $65.58 \pm 1.007 \mathrm{a}^{*}$ \\
Group III & $110.14 \pm 0.28 \mathrm{~b}^{*}$ & $4 \pm 1 \mathrm{~b}^{*}$ & $32.92 \pm 0.07 \mathrm{~b}^{*}$ & $32.09 \pm 0.075 \mathrm{~b}^{*}$ \\
Group IV & $113.44 \pm 0.325 \mathrm{c}^{*}$ & $4 \pm 0.6 \mathrm{c}^{*}$ & $36.38 \pm 0.10 \mathrm{c}^{*}$ & $41.11 \pm 0.10 \mathrm{c}^{*}$ \\
\hline
\end{tabular}

Table values are expressed by mean \pm SD of 6 samples per group. Group comparison: a-Normal (I) Vs ISO (II); b-ISO (II) Vs Drug (III); c-ISO (II) Vs Plant extract (IV). Statistical significance $(\mathrm{P}<0.05)$ indicated by*

\section{Effect of ISO and plant extract on cardiac marker enzymes}

Elevated cardiac enzymes are an indication of cardiac hypertrophy which is a key risk factor for myocardial infarction [26]. Administration of isoproterenol led to a significant $(\mathrm{P}<0.05)$ increase in levels of SGOT, SGPT and LDH levels in cardiac hypertrophic rats when compared with normal control rats. After treatment with standard Losartan drug in cardiac hypertrophic rats and plant extract to hypertrophic rats for a period of $7 \mathrm{~d}$ there was a significant decrease in the levels of SGOT, SGPT and LDH as shown in table 5 and 6.

Table 5: Levels of SGOT, SGPT and LDH in serum of control and experimental rats

\begin{tabular}{llll}
\hline Groups & Serum SGOT (IU/l) & Serum SGPT (IU/l) & Serum LDH (IU/l) \\
\hline Groups I & $0.72 \pm 0.009$ & $0.09 \pm 0.01$ & $1.08 \pm 0.017$ \\
Groups II & $0.795 \pm 0.03 \mathrm{a}$ & $0.68 \pm 0.06 \mathrm{a}^{*}$ & $1.35 \pm 0.005 \mathrm{a}^{*}$ \\
Groups III & $0.707 \pm 0.036 \mathrm{~b}^{*}$ & $0.11 \pm 0.004 \mathrm{~b}^{*}$ & $1.183 \pm 0.12 \mathrm{~b}^{*}$ \\
Groups IV & $0.682 \pm 0.057 \mathrm{c}^{*}$ & $0.08 \pm 0.02 \mathrm{c}^{*}$ & $1.064 \pm 0.15 \mathrm{c}^{*}$ \\
\hline
\end{tabular}

Table values are expressed by mean \pm SD of 6 samples per group. Group comparison: a-Normal (I) Vs ISO (II); b-ISO (II) Vs Drug (III); c-ISO (II) Vs Plant extract (IV). Statistical significance $(\mathrm{P}<0.05)$ indicated by*

Table 6: Levels of SGOT, SGPT and LDH in tissue of control and experimental rats

\begin{tabular}{llll}
\hline Groups & Tissue SGOT (IU/l) & Tissue SGPT (IU/l) & Tissue LDH (IU/l) \\
\hline Group I & $0.79 \pm 0.002$ & $0.19 \pm 0.01$ & $1.006 \pm 0.002$ \\
Group II & $0.80 \pm 0.005 \mathrm{a}^{*}$ & $0.34 \pm 0.001 \mathrm{a}^{*}$ & $1.07 \pm 0.009 \mathrm{a}^{*}$ \\
Group III & $0.78 \pm 0.001 \mathrm{~b}^{*}$ & $0.07 \pm 0.03 \mathrm{~b}^{*}$ & $1.35 \pm 0.00 \mathrm{~b}^{*}$ \\
Group IV & $0.697 \pm 0.123 \mathrm{c}^{*}$ & $0.2 \pm 0.04 \mathrm{c}^{*}$ & $1.06 \pm 0.003 \mathrm{c}^{*}$ \\
\hline
\end{tabular}

Table values are expressed by mean \pm SD of 6 samples per group. Group comparison: a-Normal (I) Vs ISO (II); b-ISO (II) Vs Drug (III); c-ISO (II) Vs Plant extract (IV). Statistical significance $(\mathrm{P}<0.05)$ indicated by*

In the present study, treatment with $C$. sinensis leaf extracts which effectively reduced both serum and tissue SGOT, SGPT and LDH levels in cardiac hypertrophic rats suggesting that the extracts of experimental plant prevent cardiac injury associated with cardiac hypertrophy.

Flavonoids, phenols, carotenoids and glycosides are the major phytoconstituent present in the $C$. sinensis. Catechin is the flavonoid compound reported to have cardioprotective activity.

\section{Effect of ISO and plant extract on enzymic antioxidants}

Regulated antioxidant system is essential for successful therapy to treat cardiac hypertrophy [27]. In isoproterenol induced cardiac hypertrophic rats, the antioxidant enzymes catalase, SOD, GPx were significantly $(\mathrm{P}<0.05)$ decreased considerably with that of the normal group. Oral administration of the aqueous extract restored the above antioxidants in experimental animals similar to that of normal control. 
Table 7: Levels of enzymatic antioxidants in serum of control and experimental rats

\begin{tabular}{llll}
\hline Groups & Catalase (IU/l) & SOD (IU/l) & GPx (IU/l) \\
\hline Group I & $40.45 \pm 0.11$ & $54.74 \pm 0.13$ & $29.67 \pm 0.1$ \\
Group II & $12.11 \pm 0.11 \mathrm{a}^{*}$ & $30.9 \pm 0.06 \mathrm{a}^{*}$ & $13.62 \pm 1.154 \mathrm{a}^{*}$ \\
Group III & $23.12 \pm 0.06 \mathrm{~b}^{*}$ & $43.0 \pm 0.19 \mathrm{~b}^{*}$ & $28.60 \pm 0.152 \mathrm{~b}^{*}$ \\
Group IV & $20.04 \pm 0.04 \mathrm{c}^{*}$ & $46.01 \pm 0.1 \mathrm{c}^{*}$ & $19.34 \pm 0.02 \mathrm{c}^{*}$ \\
\hline
\end{tabular}

Table values are expressed by mean \pm SD of 6 samples per group. Group comparison: a-Normal (I) Vs ISO (II); b-ISO (II) Vs Drug (III); c-ISO (II) Vs Plant extract (IV). Statistical significance $(\mathrm{P}<0.05)$ indicated by*

Table 8: Levels of enzymatic antioxidants in heart of control and experimental rats

\begin{tabular}{llll}
\hline Groups & Catalase (IU/l) & SOD (IU/l) & GPx (IU/l) \\
\hline Group I & $40.45 \pm 0.11$ & $54.74 \pm 0.13$ & $29.67 \pm 0.1$ \\
Group II & $12.11 \pm 0.11 \mathrm{a}^{*}$ & $30.9 \pm 0.06 \mathrm{a}^{*}$ & $13.62 \pm 1.154 \mathrm{a}^{*}$ \\
Group III & $23.12 \pm 0.06 \mathrm{~b}^{*}$ & $43.0 \pm 0.19 \mathrm{~b}^{*}$ & $28.60 \pm 0.152 \mathrm{~b}^{*}$ \\
Group IV & $20.04 \pm 0.04 \mathrm{c}^{*}$ & $46.01 \pm 0.1 \mathrm{c}^{*}$ & $19.34 \pm 0.02 \mathrm{c}^{*}$ \\
\hline
\end{tabular}

Table values are expressed by mean \pm SD of 6 samples per group. Group comparison: a-Normal (I) Vs ISO (II); b-ISO (II) Vs Drug (III); c-ISO (II) Vs Plant extract (IV). Statistical significance $(\mathrm{P}<0.05)$ indicated by*

\section{CONCLUSION}

The present work implies that the aqueous extract of $C$. sinensis leaves restored the serum and heart tissue levels of glucose, protein, cholesterol, cardiac markers enzymes (SGOT, SGPT and LDH) and enzymatic antioxidants (SOD, Catalase and GPx) which may be due to the phytochemical, Catechin present in the plant. Further studies may be taken up for the isolation and characterization of catechin and also other bioactive antioxidant and cardioprotective compounds which may exert potent anti-hypertrophic effects.

\section{ACKNOWLEDGEMENT}

Thanks to PSG Institute of Medical Sciences and research and PSG Institutional Animal Ethics Committee, Coimbatore, India and the Committee for the Purpose of Control and Supervision of Experiments on Animals (CPCSEA for providing animal ethical clearance. Thanks to the Botanical Survey of India, for the plant authentication. Thanks to Ponmani and Co Pvt. Ltd., Coimbatore for providing Isoproterenol (Sigma).

\section{AUTHORS CONTRIBUTIONS}

All authors contributed equally in designing the work, performing and interpreting the experiments followed by manuscript preparation.

\section{RESPONSE TO COMMENTS}

We thank the reviewers and the editorial board for their valuable comments and we hereby declare that the applicable revisions were carried out cautiously in the article order to meet the scientific needs of the study.

\section{CONFLICT OF INTERESTS}

There is no conflict of interest among the authors

\section{REFERENCES}

1. Frey N, Katus HA, Olson EN, Hill JA. Hypertrophy of the heart: a new therapeutic target. Circulation 2004;109:1580-9.

2. Carreno JE, Apablaza F, Ocaranza MP, Jalil JE. Cardiac hypertrophy: molecular and cellular events. Rev ESP Cardiol 2006;59:473-86.

3. Bopanna KN, Kannan J, Godgil S, Balaraman R, Rathod SP. Antidiabetic and Antihyperlipidemic effects of Neem seed kernel powder on alloxan diabetic rabbits. Indian J Pharmacol 1997;29:162-72.

4. Chu DC, Juneja LR. General chemical composition of green tea and its infusion. In: Juneja LR, Chu DC, Kim M. [Eds] Chemistry and application of green tea. CRC press, Boca Raton; 1997. p. 13-22.
5. Gramza A, Korczak J. Tea constituents (Camellia sinensis L.) as antioxidants in lipid systems. Trends Food Sci Tech 2005; 16:351-8

6. Hara Y. Green tea: health benefits and applications. Bola Raton FL. CRL Press: Taylor and Francis group; 2001. p. 252.

7. Cabrera C, Artacho R, Gimenez R. Beneficial effects of green tea: a review. J America College Nutr 2006;25:79-99.

8. Nie G, Cao Y, Zhao B. Protective effects of green tea polyphenols and their major components, $(-)$. Epigallocatechin-3-gallate (EGCG), on 6-hydroxydopamine-induced in PC 12 cells. Redox Rep 2002;7:171-7.

9. Huang $\mathrm{Q}, \mathrm{Wu} \mathrm{LJ}$, Tashiro S, Gao HY, Onodera S, Ikejima T. (+) catechin, an ingredient of green tea, protects murine microglia from Oxidative stress-induced DNA damage and cell cycle arrest. J Pharmacol Sci 2005;98:16-24.

10. Schuppan DJ, Jia B, Brikhaus EG, Hahn. Herbal products for liver disease: a therapeutic challenge for the new millennium. Hepatology 1999;30:1099-104.

11. Tsuneki H, Ishizuk M, Terasawa M, Jin-Bi W, Sasaoka T, Kimura I. Effect of green tea on blood glucose levels and serum proteomic patterns $(\mathrm{db} / \mathrm{db})$ mice and on glucose metabolism in healthy humans. BMC Pharmacol 2004;26:18-28.

12. Chisaka T, Matsuda H, Kubomura Y, Mochizuki M, Yamahara I, Fujimura $H$. The effect of crude drugs on experimental hypercholesterolemia: mode of action by (-) epigallocatechin gallate in tea leaves. Chem Pharm Bull 1998;36:227-33.

13. Arakawa H, Maeda M, Shimamura T. Role of hydrogen peroxide in bactericidal action of catechin. Biol Pharm Bull 2004;27:277-81.

14. Anwar E, Utami TD, Ramadon D. Transfersomal gel containing green tea (Camellia sinensis L. Kuntze) leaves extract: increasing in vitro penetration. Asian J Pharm Clin Res 2017;10:1-5.

15. Permatasari IA, Jufri M. Formulation of nicosomal gel containing green tea extract (Camellia sinensis L. Kuntze) using thin-layer hydration. Int J Appl Pharm 2017;9 Suppl 1:38-43.

16. Murali B, Upadhyaya UM, Goyal RK. Effect of chronic treatment with Enicostemma littorale in non-insulin dependent diabetic (NIDDM) rats. J Ethnopharmacol 2002;81:199-204.

17. Zhang $\mathrm{S}$, Tang $\mathrm{F}$, Yang $\mathrm{Y}, \mathrm{Lu} \mathrm{M}$, Luan $\mathrm{A}$, Zhang J, et al. Astragaloside IV protects against isoproterenol-induced cardiac hypertrophy by regulating NF- $\mathrm{\kappa B} / \mathrm{PGC}-1 \alpha$ signaling mediated energy biosynthesis. Plosone 2015;1-18 https://doi.org/10.1371/journal.pone.0118759

18. Shimada JY, Passeri JJ, Baggish LA, Callaghan OC, Lowry PA, Yannekis G, et al. Effects of losartan on left ventricular hypertrophy and fibrosis in patients with nonobstructive hypertrophic cardiomyopathy. JACC Heart Fail 2013;1:480-7.

19. Upaganlawar A, Gandhi C, Balaraman R. Effect of green tea and Vitamin E combination in isoproterenol induced myocardial infarction in rats. Plant Foods Human Nutr 2009;64:75-80. 
20. Lowry $\mathrm{OH}$, Rosenbrough NJ, Farr AL, Randall RJ. Protein measurement with the folin-phenol reagents. J Biol Chem 1951;193:265-75

21. Kakkar P, Das B, Vishwanathan PN. A modified spectrophotometric assay of superoxide dismutase. Indian J Biochem Biophys 1984;21:130-2.

22. Sinha AK. Colorimetric assay of catalase. Anal Biochem 1972;47:389-94.

23. Rotruck JT, Pope AL, Ganther HE, Swasson AS, Haseman DG, Howkstra WG. Selenium: biochemical role as a component of glutathione peroxidase. Science 1973;779:588-90.

24. Yang J, Chen NY, Xu XZ, Mou Y, Zheng RL. Alteration of RhoA prenylation ameliorates cardiac and vascular remodeling in spontaneously hypertensive rats. Cell Physiol Biochem 2016;39:229-41.

25. Al-Rasheed MN, Al-Oteibi MM, Al-Manee ZR, Al-Shareef AS, AlRasheed MN, Hasan HI, et al. Simvastatin prevents isoproterenolinduced cardiac hypertrophy through modulation of the JAK/STAT pathway. Drug Design Development Ther 2015; 9:3217-29.

26. Hamada M, Shigematsu Y, Ohtani T, Ikeda S. Elevated cardiac enzymes in hypertrophic cardiomyopathy patients with heart failure. J Japanese Circulation Soc 2016;80:218-26.

27. Shen XC, Qian ZY. Effects of crocetin on antioxidant enzymatic activities in cardiac hypertrophy induced by norepinephrine in rats. Pharmazie 2006;61:348-52. 